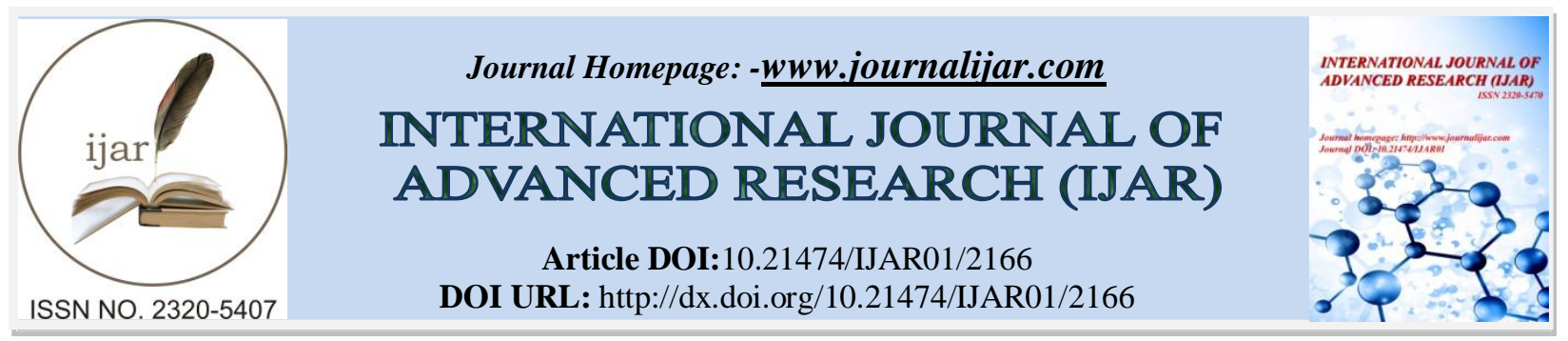

RESEARCH ARTICLE

\title{
A REVIEW ARTICLE ON GLIMEPERIDE: AN ORAL HYPOGLYCAEMIC DRUG
}

\section{Anupamaa Tiwari, Manoj Kumar Mishra, KanikaNayak, GarimaVerma, Sunil Kumar Yadav and Ashutosh Shukla.}

Shambhunath Institute of Pharmacy, Jhalwa, Allahabad, Uttar Pradesh-211012, India.

\section{Manuscript Info}

Manuscript History

Received: 26 September 2016

Final Accepted: 29 October 2016

Published: November 2016

\section{Abstract}

Glimepiride is a second generation sulfonylurea of oral hypoglycaemic drug that stimulates the B-cells of the pancreases to secrete insulin. In this article there is full information on all the research work and development done on glimepiride drug. The main motive is to compile all the works which have done.

Copy Right, IJAR, 2016,. All rights reserved.

\section{Introduction:-}

Glimepiride is a sulfonyl urea used to treat type -II diabetes mellitus. Molecular formula of glimepiride is $\mathrm{C}_{24} \mathrm{H}_{34} \mathrm{~N}_{4} \mathrm{O}_{5} \mathrm{~S}$ with a molecular mass of about $490.617 \mathrm{~g} / \mathrm{mol}^{[1]}$. It belongs to class-II of Biopharmaceutical classification system. It is completely insoluble in water, acidic media and slightly soluble in various buffers and organic solvents ${ }^{[2]}$. It is administered orally; insoluble in water, slightly soluble in methylene chloride(Dichloromethane), very slightly soluble in methanol and soluble in Dimethyl Sulfoxide (DMSO) ${ }^{[1,3]}$. Glimepirideshows low $\mathrm{pH}$ dependent solubility. Inacidic and neutral aqueous media, glimepiride exhibits very poorsolubility at $37^{0} \mathrm{C}(<0.004 \mathrm{mg} / \mathrm{ml})$. In media $\mathrm{pH}>7$, solubility of drug isslightly increased to $0.02 \mathrm{mg} / \mathrm{ml}$. These poorlywater soluble drugsprovide challenges to deliver them in an active and absorbable form tothe desired absorption site using physiologically safe excipients ${ }^{[4-6]}$. This poor solubility may cause poor dissolution and unpredicted bioavailability. It is practically insoluble in water and other aqueous media. However, the drawback of this potentially useful hypoglycemic agent is that it is highly hydrophobic and practically insoluble in water ${ }^{[7,8]}$.

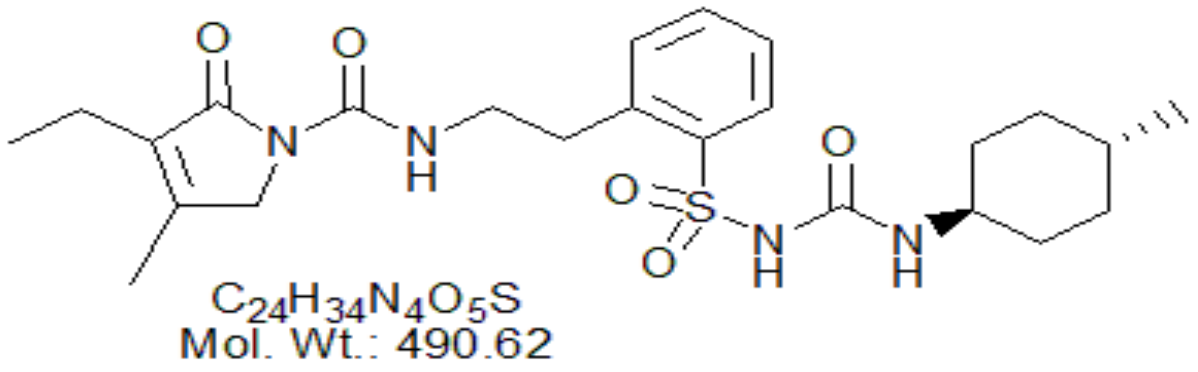

Fig 1:-Structure of Glimepiride

\section{Mechanism of action:-}

The primary mechanism of action of glimepiride for lowering blood glucose levels seems to be dependent on stimulating the release of insulin from the functioning pancreatic cells. Glimepiride acts by binding to ATP sensitive potassium channel receptors on the pancreatic cell surface, which reduces potassium conductance causing 
depolarization of the membrane. Calcium ion reflux is stimulated by the membrane depolarization through voltagesensitive calcium channels. This increased intracellular calcium ion concentration induces the secretion of insulin. It can be employed for concomitant use with metformin, thiazolidinedione, insulin and alpha-glucosidase inhibitors for treatment of type-2 (noninsulin dependent) diabetes mellitus. It is completely absorbed from the gastrointestinal tract when it is administered orally. The possible side effects are severe hypoglycemic reactions with coma, seizure, or other neurological impairment. The other reported side effects of sulfonylureas includes clolestatic jaundice, nausea and vomiting, aplastic and hemolytic anemias, agranulocytosis, generalized hypersensitivity reactions, and rashes $^{[1,9]}$.

\section{Extra-pancreatic action:-}

After chronic administration, the insulinaemic action of sulfonylureas declinesprobably due to down regulation ofsulfonylurea receptors on $\beta$-cells, but improvement in glucose tolerance is maintained. In thisphase, they sensitize the target tissues (especiallyliver) to the action of insulin. This is due toincrease in number of insulin receptorsand / or a postreceptoraction-improving translation ofreceptor activation. It is hypothesized that longterm improvement in carbohydrate toleranceleads to a decreased insulin concentration inblood which reverses the down regulation of insulinreceptors-apparent increase in their number. A direct extra-pancreatic action of sulfonylureas to increase insulin receptors on target cells and to inhibit gluconeogenesis in liver has been suggested, but appears to have little clinical relevance ${ }^{[10]}$.

\section{Works done on glimeperide:-}

There are a number of works done on drug glimepiride. Following are the works done on glimeperide drug:

* Glimepiride (GMP) was selected as a model drug for dissolution enhancement studies in the present investigation. Attempts were made to enhance the dissolution of GMP using a solid dispersion (SD) technique. SDs of GMP-PXM 188 (Poloxamer 188) were prepared in different ratios using the melting method, and then tablets of best formulation of SD were formulated by using direct compression method. SDs were evaluated for XRD, SEM, In-vitrodissolution profiles, and dissolution efficiency, and developed tablet formulations were evaluated for various pharmaceutical characteristics viz. hardness, \% friability, weight variation, drug content, disintegration time, In-vitrodissolution profiles, and dissolution efficiency Among different formulations of SDs, SD containing drug is to polymer ratio $1: 4$ gives best dissolution profile and dissolution efficiency and among tablet formulations, formulations containing 5\% croscarmellose sodium gives best disintegration and dissolution profiles compared with other formulations. Results showed that poloxamer is a promising polymer for enhancing the solubility of GMP ${ }^{[11]}$.

- Solid dispersion (SD) of Glimepride is prepared by dissolving drug and polyvinyl pyrrolidine K30 in Dichloromethane and the solvent is removed by rotary evaporator under reduced pressure. The solubility increased around twenty times greater when drug and carrier is used in 1:10 ratios. The Oro dispersible tablets were prepared by using Sodium starch glycolate, cross caramellose sodium, pre-gelatinized starch and polacrilin potassium as super disintegrants. The rapid disintegration $(24 \mathrm{sec})$ is obtained to polacrilinpotassium $(10 \%)$ and maximum drug release $(85.6 \%)$ obtained in $10 \mathrm{~min}$. From these results it is concluded that solubility of glimepride is increased by preparing solid dispersion and rapid bioavailability is observed by preparing orodispersible tablets ${ }^{[2]}$.

* The SDs of Glimepiride with PEG 20000 were prepared with 1:1, 1:3 and 1:5 (Glimepiride:PEG 20000) ratio by melting method. The primary objective of the present study was to investigate the physicochemical properties of glimepiride in SDs with PEG 20000. The possible interactions between glimepiride and PEG 20000 in both solid state and liquid states were investigated. Interaction in the solid state was investigated by FTIR and XRD. Interaction in solution was studied by phase solubility analysis and dissolution experiments. The SDs of glimepiride with PEG 20000 exhibited enhanced dissolution rate of glimepiride, and the rate increased with increasing concentration of PEG 20000 in SDs. Mean dissolution time (MDT) of glimepiride decreased significantly after preparation of SDs and physical mixture with PEG 20000. The FTIR spectroscopic studies showed the stability of glimepiride and absence of well-defined glimepiride-PEG 20000 interaction. The XRD studies indicated the amorphousstate of glimepride with PEG $20000^{[12]}$.

* Glimepiride (GMP) was selected as a model drug for dissolution enhancement studies in the present investigation. Attempts were made to enhance the dissolution of GMP using a SD technique. SDs of GMP withpolyvinylpyrrolidone(PVP K 30) was prepared in different ratios using solvent evaporation method and then tablets of best formulation of SD were formulated by using direct compression method. Tablet formulations were prepared by direct compression technique using super-disintegrants; crospovidone in different 
concentrations. SDs were evaluated for FTIR, XRD, SEM, In-vitrodissolution profiles, and developed tablet formulations wereevaluated for various pharmaceutical characteristics viz. hardness, \% friability, weight variation, drug content, disintegration time, In-vitrodissolution profiles ${ }^{[4]}$.

* Glimepiride (GMP) is poorly water soluble drug, so solubility is the main constraint for its oral bioavailability. The objective of the research project is to enhance of the solubility of Glimepiride by using solid dispersion technique. The polymers used were Poloxamer 188 and Poloxamer 407 and solid dispersions were prepared by kneading method. The solubility study was carried out to study the effect of polymers on solubility of Glimepiride. The prepared solid dispersions were characterized by In-vitro solubility Study, \% drug content; Fourier transforms spectroscopy (FTIR), In-vitro drug dissolution to identify the physicochemical interaction between drug and excipients. The dissolution studies of solid dispersion were performed by using USP II apparatus. The solid dispersion prepared with Poloxamer 188 showed better drug release as compared to solid dispersion prepared with Poloxamer $407^{[7]}$.

* The rationale of this study was to improve the solubility, dissolution rate and sustainedrelease of the drug. Glimepiride cubosomes were prepared by Top down approach employing Glycerylmonooleate (GMO) as lipid phase vehicle, Poloxamer 407 as stabilizer and distilled water as aqueous phase. The resultant cubosome dispersion were characterized by encapsulation efficiency, In-vitro drug release, particle size, zeta potential, FTIR and SEM. Optimized formulation (F5) showed a maximum drug release of $71 \%$ in 6 hours, particle size of $88.7 \mathrm{~nm}$ and zeta potential of $43.6 \mathrm{mV}$. Glimepiride cubosomal Capsules were prepared with the optimized cubosomal dispersion, by using a new technique starch and aerosil were used as granulating agents to obtain a wet mass. Then the wet mass was passed through sieve no. 16 to form granules. Then the granules were dried in hot air oven. The dried granules were filled into capsules. The granules were evaluated for SEM, zeta potential, flow properties and In-vitro drug release. Optimized capsule formulation (C2) contains starch showed a maximum drug release of $49 \%$ in 6 hours, particle size of $213 \mathrm{~nm}$ and zeta potential of $-159 \mathrm{mV}$. In-vitro release kinetics exhibited sustained release up to 6 hours and followed non- Fickian diffusion. Results suggest that GMO cubosomes, as lipid nanovectors, could significantly enhance oral efficacy when compared to Glimepiride powder ${ }^{[13]}$.

* The main objective of the study was to increase the amount of dissolved drug molecules at the absorption site by increasing the dissolution rate, since for class II drugs like glimepiride, In-vivo dissolution rate is rate limiting step in drug absorption. Surface solid dispersion (SSD) was selected as the method of choice since it would be easier in subsequent formulating and processing of tablets. The carriers used were crospovidone, croscarmellose, sodium starch glycolate, pre-gelatinized starch, Avicel PH 101 and potato starch. The SSDs were prepared at various drug-to-carrier weight ratios by solvent evaporation method. The optimized SSD was characterized and formulated intotablets ${ }^{[14]}$.

* A novel matrix controlled transdermal systems of anti-diabetic drug glimepiride were prepared using natural polymer chitosan for the extended and controlled delivery of the drug. Characterization was done by physicochemical studies. Optimization of the system was done using In-vitrodrug permeation studies through rat skin. Skin irritation tests and pharmacokinetic evaluations were carried out in healthy rats. Blood glucose reducing hypoglycemic activity of the systems was studied in diabetic rats ${ }^{[15]}$.

* Glimepiride is an oral hypoglycaemic agent and is completely absorbed after oral administration but it is subjected to liver metabolism which contributes to its efficacy with single oral administration. To increase the patient compliance and to have convenience of administration, nasal gel of Glimepiride was prepared using mucoadhesive polymers which may increases its residence time there by subsequent bioavailability. Nasal formulation with the controlled action of drug is a good alternative. Challenges in the development of nasal formulation include low residence time. Mucociliary clearance can be overcome by developing a mucoadhesive formulation $^{[16]}$.

* The main objective of this present research work is to achieve sustained release of Glimepiride and to enhance the gastrointestinal residence time, for this purpose mucoadhesive microbeads were formulated by employing Ionic gelation method with HPMC and Na-CMC as coating polymers. Formulated mucoadhesive microbeads were properly evaluated for size distribution, tapped density entrapment efficiency, wall thickness, drug release studies, SEM and GI residence time. In this present research influence of polymer on rate of drug release and concentration of polymer coat on rate of drug release from the Glimepiride mucoadhesive microbeads were studied. The rate of drug release was found to be decreased by increasing the concentration of the coat polymer $^{[17]}$.

* The objective of this study was to develop sustained release tablets of glimepiride by wet granulation method based on combination of hydrophilic (HPMC15cps, HPC) and hydrophobic (Ethyl cellulose) polymers. The 
drug excipient mixtures were subjected to preformulation studies. The tablets were subjected to physicochemical studies, In-vitro drug release, kinetic studies and stability studies ${ }^{[18]}$.

* Glimepiride acts as an insulin secretagogue. To provide the patients with the most convenient mode of administration, there was a need to develop immediate release dosage form, particularly one that disintegrates rapidly and disperses and helps in enhancing the Bioavailability of the drug. Glimepiride immediate release tablets were formulated by using wet granulation method and povidone $\mathrm{k} 30$, starch as binders, croscarmellose sodium, sodium starch glycolate, crospovidone as disintegrants, lactose monohydrate as diluent and magnesium stearate as lubricant.The tablets were evaluated forpre-compression and post-compression parameters after conducting preformulation studies. All the parameters were within the pharmacopoeial limits and the drug disintegrate on time was less and theIn-vitro dissolution studies showed that the drug release was fast ${ }^{[19]}$.

* The main objective of the research was to formulate directly compressible fast disintegrating tablets of glimepiride by using different super disintegrants such as crospovidone, croscarmellose sodium, sodium starch glycolate and L-HPC in various concentrations ${ }^{[20]}$.

* The purpose of the present study was to design an inlayered tablet consisting of glimepiride core tablet for immediate release to produce immediate therapeutic effect, which was inserted inside the cup of metformin hydrochloride for sustained deliver of metformin hydrochloride. The inner core portion was design using superdisintegrants for immediate release and the outer cup portion was designed as matrix formulations using polymers such as Hydroxypropyl methyl cellulose (HPMC) and Poly vinyl pyrollidine (PVP) to modulate the drug release ${ }^{[21]}$.

* The purpose of preparing self microemulsifying drug delivery system in this work is to enhance the solubility and oral bioavailability of poorly water soluble drug, Glimepiride. Self-micro emulsifying drug delivery system (SMEDDS) are the isotropic mixture of surfactant, co-surfactant and oil incorporated with drug. In the aqueous media, gastro intestinal motility emulsification takes place. Glimepiride was undergone solubility studies in various surfactants, co-surfactants and oils ${ }^{[22]}$.

* The present study reveals the formulation and evaluation method of glimepiride loaded liposomes. The liposomal formulationsof glimepiride were prepared by using phosphotidylcholine (lecithin) and cholesterol by using thin film hydration method ${ }^{[23]}$.

* The aim of the present study was to design and develop the best sustained release formulations of glimepiride tablets, to evaluate the release pattern and to compare it with that of immediate release tablets. The study was designed to achieve maximum efficacy for the treatment of type- 2 diabetes mellitus.Glimepiride sustained release tablets were prepared by direct compression method using different ratios of various release retarding polymers such as carbopol, ethyl cellulose, methocel K4 MCR, methocel K15 MCR, methocel K100 MCR and xanthum gum. These formulations were also compared with glimepiride immediate release tablets. The prepared tablets were subjected to various physical parameter tests including weight variation, friability, hardness, thickness, diameter,etc. In-vitrodissolution studies of the formulations were done at $\mathrm{pH} 6.8$ in phosphate buffer using USP apparatus 2 (paddle method) at $50 \mathrm{rpm}^{[24]}$.

* The present research work is an attempt to develop and evaluate Nanosuspension of Glimepiride in order to improve the solubility and bioavailability of poorly water soluble drugs. Nanosuspensions of Glimepiride were developed with different ratios of Urea and poly vinyl pyrrolidine (PVP) combinations by nanoprecipitation technique. Nanoprecipitation method being simple and less sophisticated was optimized for the preparation of nanosuspension $^{[25]}$.

* The objective of this work was to prepare Glimepiride (1mg) fast dissolving tablets by wet granulation method. Glimepiride was the drug of choice because of its low dose. The prepared Glimepiride fast dissolving tablet (FDT) were found to have faster onset of action than the conventional Glimepiride tablets. Also, they were effective in lowering fasting blood glucose levels. Glimepiride fast dissolving tablets were prepared using super disintegrants like Croscarmellose sodium, cross povidone, sodium starch glycollate by employing wet granulation technique. Prepared tablets were evaluated for angle of repose, hardness, friability, disintegration, In-vitro dissolution studies. Dissolution was performed using USP type II apparatus at a temperature of $37 \pm 0.5^{\circ} \mathrm{c}, 50 \mathrm{RPM}, 900 \mathrm{ml} \mathrm{pH} 6.8$ phosphate buffer and samples were estimated spectrophotometrically at $228 \mathrm{~nm}$. The In-vitro dissolution studies shown that tablets prepared using cross povidone superdisintegrant showed better drug release when compared to other super disintegrants ${ }^{[26]}$. 
Marketed products of glimepiride:-

Table No. 1:-List of marketed products of Glimeperide drug

\begin{tabular}{|c|c|c|c|c|c|}
\hline S.No & Brand Name & Manufacturers & Type & Unit & Uses \\
\hline 1 & Amaryl (2 mg) & $\begin{array}{l}\text { Sun Pharmaceutical Industries } \\
\text { Ltd. }\end{array}$ & Tablet & $2 \mathrm{mg}$ & $\begin{array}{l}\text { Proper control of diabetes } \\
\text { may also lessen your risk of } \\
\text { a heart attack or stroke }\end{array}$ \\
\hline 2 & Amaryl (3 mg) & Nicholas Piramal India Ltd. & Tablet & $3 \mathrm{mg}$ & $\begin{array}{l}\text { lower the blood sugar levels } \\
\text { in type } 2 \text { diabetes mellitus }\end{array}$ \\
\hline 3 & Asoride & Cipla Limited & Tablet & $1 \mathrm{mg}$ & Type- 2 diabetes mellitus \\
\hline 4 & Bepride (4mg) & $\begin{array}{l}\text { Sun Pharmaceutical Industries } \\
\text { Ltd. }\end{array}$ & Tablet & $4 \mathrm{mg}$ & $\begin{array}{l}\text { lower the blood sugar levels } \\
\text { in type } 2 \text { diabetes mellitus }\end{array}$ \\
\hline 5 & Betaglim (1mg) & Panacea Biotec Ltd & Tablet & $1 \mathrm{mg}$ & $\begin{array}{l}\text { control blood sugar in } \\
\text { people with type } 2 \text { diabetes }\end{array}$ \\
\hline 6 & Blisto (2 mg) & Unichem Laboratories Ltd. & Tablet & $2 \mathrm{mg}$ & $\begin{array}{l}\text { lower the blood sugar levels } \\
\text { in type } 2 \text { diabetes mellitus }\end{array}$ \\
\hline 7 & Cgryl & $\begin{array}{ll}\text { Centaur } & \text { Pharmaceuticals } \\
\text { Pvt.Ltd. } & \end{array}$ & Tablet & $1 \mathrm{mg}$ & $\begin{array}{l}\text { lower the blood sugar levels } \\
\text { in type } 2 \text { diabetes mellitus }\end{array}$ \\
\hline 8 & Diaglim & Dr Reddy Laboratories Ltd & Tablet & $2 \mathrm{mg}$ & $\begin{array}{l}\text { control blood sugar in } \\
\text { people with type } 2 \text { diabetes. }\end{array}$ \\
\hline 9 & Diagraph (2 mg) & BiomaxBiotechnicsPvt Ltd & Tablet & $2 \mathrm{mg}$ & $\begin{array}{l}\text { control blood sugar in } \\
\text { people with type } 2 \text { diabetes. }\end{array}$ \\
\hline 10 & Diapride & B \& B (Micro Labs Ltd.) & Tablet & $1 \mathrm{mg}$ & $\begin{array}{l}\text { lower the blood sugar levels } \\
\text { in type } 2 \text { diabetes mellitus }\end{array}$ \\
\hline 11 & Diaset $(1 \mathrm{mg})$ & StadmedPvt Ltd & Tablet & $1 \mathrm{mg}$ & $\begin{array}{l}\text { lower the blood sugar levels } \\
\text { in type } 2 \text { diabetes mellitus }\end{array}$ \\
\hline 12 & Diaswich (2 mg) & Piramal Healthcare & Tablet & $2 \mathrm{mg}$ & $\begin{array}{l}\text { lower the blood sugar levels } \\
\text { in type } 2 \text { diabetes mellitus }\end{array}$ \\
\hline 13 & Dibiglim & Sandoz (Novartis India Ltd) & Tablet & $1 \mathrm{mg}$ & $\begin{array}{l}\text { lower the blood sugar levels } \\
\text { in type } 2 \text { diabetes mellitus }\end{array}$ \\
\hline 14 & Emperide & Emcure Pharmaceuticals Ltd. & Tablet & $1 \mathrm{mg}$ & $\begin{array}{l}\text { lower the blood sugar levels } \\
\text { in type } 2 \text { diabetes mellitus }\end{array}$ \\
\hline 15 & Euglim (4 mg) & Indoco Remedies Ltd & Tablet & $4 \mathrm{mg}$ & $\begin{array}{l}\text { lower the blood sugar levels } \\
\text { in type } 2 \text { diabetes mellitus }\end{array}$ \\
\hline 16 & Flexiglim & Unichem Laboratories Ltd. & Tablet & $\begin{array}{l}0.5 \mathrm{~m} \\
\mathrm{~g}\end{array}$ & $\begin{array}{l}\text { lower the blood sugar levels } \\
\text { in type } 2 \text { diabetes mellitus }\end{array}$ \\
\hline 17 & Flexiglim (4 mg) & $\begin{array}{ll}\text { Otsira(Aristo Pharmaceuticals } \\
\text { Pvt Ltd.) }\end{array}$ & Tablet & $4 \mathrm{mg}$ & $\begin{array}{l}\text { lower the blood sugar levels } \\
\text { in type } 2 \text { diabetes mellitus }\end{array}$ \\
\hline 18 & Gamaryl (3 mg) & $\begin{array}{ll}\text { Stancare } & \text { (Ranbaxy } \\
\text { Laboratories Ltd) } & \\
\end{array}$ & Tablet & $3 \mathrm{mg}$ & $\begin{array}{l}\text { lower the blood sugar levels } \\
\text { in type } 2 \text { diabetes mellitus }\end{array}$ \\
\hline 19 & Gemer & Xieon Lifesciences Pvt. Ltd. & Tablet & $1 \mathrm{mg}$ & $\begin{array}{l}\text { lower the blood sugar levels } \\
\text { in type } 2 \text { diabetes mellitus }\end{array}$ \\
\hline 20 & Gepride & Medley Pharmaceuticals Ltd. & Tablet & $1 \mathrm{mg}$ & $\begin{array}{l}\text { lower the blood sugar levels } \\
\text { in type } 2 \text { diabetes mellitus }\end{array}$ \\
\hline 21 & Geriglim & Alembic Limited. & Tablet & $1 \mathrm{mg}$ & $\begin{array}{l}\text { lower the blood sugar levels } \\
\text { in type } 2 \text { diabetes mellitus }\end{array}$ \\
\hline 22 & Geriglim (2 mg) & $\begin{array}{l}\text { CND (ZydusCadila Healthcare } \\
\text { Ltd) }\end{array}$ & Tablet & $2 \mathrm{mg}$ & $\begin{array}{l}\text { lower the blood sugar levels } \\
\text { in type } 2 \text { diabetes mellitus }\end{array}$ \\
\hline 23 & Gip (2 mg) & Win-Medicare Limited & Tablet & $2 \mathrm{mg}$ & $\begin{array}{l}\text { lower the blood sugar levels } \\
\text { in type } 2 \text { diabetes mellitus }\end{array}$ \\
\hline 24 & Glador & Lupin Laboratories Ltd. & Tablet & $1 \mathrm{mg}$ & $\begin{array}{l}\text { lower the blood sugar levels } \\
\text { in type } 2 \text { diabetes mellitus }\end{array}$ \\
\hline 25 & Gleam (1mg) & Franco Indian Remedies & Tablet & $1 \mathrm{mg}$ & $\begin{array}{l}\text { lower the blood sugar levels } \\
\text { in type } 2 \text { diabetes mellitus }\end{array}$ \\
\hline
\end{tabular}




\begin{tabular}{|c|c|c|c|c|c|}
\hline 26 & Gli (2 mg) & Cadila Pharmaceuticals Ltd. & Tablet & $2 \mathrm{mg}$ & $\begin{array}{l}\text { lower the blood sugar levels } \\
\text { in type } 2 \text { diabetes mellitus }\end{array}$ \\
\hline 27 & Glifix & Aurobindo Pharma Ltd. & Tablet & $1 \mathrm{mg}$ & $\begin{array}{l}\text { lower the blood sugar levels } \\
\text { in type } 2 \text { diabetes mellitus }\end{array}$ \\
\hline 28 & Glimcip & Cipla Limited & Tablet & $1 \mathrm{mg}$ & $\begin{array}{l}\text { lower the blood sugar levels } \\
\text { in type } 2 \text { diabetes mellitus }\end{array}$ \\
\hline 29 & Glimcom & Comed Chemicals Pvt Ltd & Tablet & $1 \mathrm{mg}$ & $\begin{array}{l}\text { lower the blood sugar levels } \\
\text { in type } 2 \text { diabetes mellitus }\end{array}$ \\
\hline 30 & Glime (2 mg) & $\begin{array}{l}\text { Healtheon (Glenmark } \\
\text { Pharmaceuticals Ltd.) }\end{array}$ & Tablet & $2 m g$ & $\begin{array}{l}\text { lower the blood sugar levels } \\
\text { in type } 2 \text { diabetes mellitus }\end{array}$ \\
\hline 31 & Glimestar & $\begin{array}{l}\text { Discovery } \quad \text { (Mankind } \\
\text { Pharmaceuticals Pvt. Ltd.) }\end{array}$ & Tablet & $1 \mathrm{mg}$ & $\begin{array}{l}\text { lower the blood sugar levels } \\
\text { in type } 2 \text { diabetes mellitus }\end{array}$ \\
\hline 32 & Glimfit $(2 \mathrm{mg})$ & US Vitamins Limited & Tablet & $2 \mathrm{mg}$ & $\begin{array}{l}\text { lower the blood sugar levels } \\
\text { in type } 2 \text { diabetes mellitus }\end{array}$ \\
\hline 33 & Glimfit (4 mg) & $\begin{array}{l}\text { Sun Pharmaceutical Industries } \\
\text { Ltd. }\end{array}$ & Tablet & $4 \mathrm{mg}$ & $\begin{array}{l}\text { lower the blood sugar levels } \\
\text { in type } 2 \text { diabetes mellitus }\end{array}$ \\
\hline 34 & Glimitab (1mg) & $\begin{array}{l}\text { Centaur } \\
\text { Pvt.Ltd. }\end{array}$ & Tablet & $1 \mathrm{mg}$ & $\begin{array}{l}\text { lower the blood sugar levels } \\
\text { in type } 2 \text { diabetes mellitus }\end{array}$ \\
\hline 35 & Glimkap & $\begin{array}{l}\text { Karnataka Antibiotics } \\
\text { Pharmaceuticals Ltd. }\end{array}$ & Tablet & $1 \mathrm{mg}$ & $\begin{array}{l}\text { lower the blood sugar levels } \\
\text { in type } 2 \text { diabetes mellitus }\end{array}$ \\
\hline 36 & Glimpid (2mg) & $\begin{array}{ll}\text { Cardiovascular } & \text { (Ranbaxy } \\
\text { Laboratories Ltd) } & \end{array}$ & Tablet & $2 \mathrm{mg}$ & $\begin{array}{l}\text { lower the blood sugar levels } \\
\text { in type } 2 \text { diabetes mellitus }\end{array}$ \\
\hline 37 & Glimpid (4 mg) & Intas Laboratories Pvt Ltd & Tablet & $4 \mathrm{mg}$ & $\begin{array}{l}\text { lower the blood sugar levels } \\
\text { in type } 2 \text { diabetes mellitus }\end{array}$ \\
\hline 38 & Glimser (2 mg) & $\begin{array}{l}\text { Alembic Chemical Works Co } \\
\text { Ltd }\end{array}$ & Capsule & $2 \mathrm{mg}$ & $\begin{array}{l}\text { lower the blood sugar levels } \\
\text { in type } 2 \text { diabetes mellitus }\end{array}$ \\
\hline 39 & Glimulin (4 mg) & Piramal Healthcare & Tablet & $4 \mathrm{mg}$ & $\begin{array}{l}\text { lower the blood sugar levels } \\
\text { in type } 2 \text { diabetes mellitus }\end{array}$ \\
\hline 40 & Glimy & Dr Reddy Laboratories Ltd & Tablet & $1 \mathrm{mg}$ & $\begin{array}{l}\text { lower the blood sugar levels } \\
\text { in type } 2 \text { diabetes mellitus }\end{array}$ \\
\hline 41 & Glimy (4 mg) & Intas Laboratories Pvt Ltd & Tablet & $4 \mathrm{mg}$ & $\begin{array}{l}\text { lower the blood sugar levels } \\
\text { in type } 2 \text { diabetes mellitus }\end{array}$ \\
\hline 42 & Glimz & Wallace Pharmaceuticals Ltd. & Tablet & $1 \mathrm{mg}$ & $\begin{array}{l}\text { lower the blood sugar levels } \\
\text { in type } 2 \text { diabetes mellitus }\end{array}$ \\
\hline 43 & Glista-OD & Cadila Pharmaceuticals Ltd. & Tablet & $1 \mathrm{mg}$ & $\begin{array}{l}\text { lower the blood sugar levels } \\
\text { in type } 2 \text { diabetes mellitus }\end{array}$ \\
\hline 44 & Glista -OD (2 mg) & Unichem Laboratories Ltd. & Tablet & $2 \mathrm{mg}$ & $\begin{array}{l}\text { lower the blood sugar levels } \\
\text { in type } 2 \text { diabetes mellitus }\end{array}$ \\
\hline 45 & Glp (2 mg) & IPCA Laboratories Ltd. & Tablet & $2 \mathrm{mg}$ & $\begin{array}{l}\text { lower the blood sugar levels } \\
\text { in type } 2 \text { diabetes mellitus }\end{array}$ \\
\hline 46 & Glucoryl & Alkem Laboratories Ltd & Tablet & $1 \mathrm{mg}$ & $\begin{array}{l}\text { lower the blood sugar levels } \\
\text { in type } 2 \text { diabetes mellitus }\end{array}$ \\
\hline 47 & Glycirid & Indi Pharma Pvt Ltd & Tablet & $1 \mathrm{mg}$ & $\begin{array}{l}\text { lower the blood sugar levels } \\
\text { in type } 2 \text { diabetes mellitus }\end{array}$ \\
\hline 48 & Gride & Unichem Laboratories Ltd. & Tablet & $3 \mathrm{mg}$ & $\begin{array}{l}\text { lower the blood sugar levels } \\
\text { in type } 2 \text { diabetes mellitus }\end{array}$ \\
\hline 49 & Isryl (2 mg) & Systopic Laboratories (P) Ltd. & Tablet & $2 \mathrm{mg}$ & $\begin{array}{l}\text { lower the blood sugar levels } \\
\text { in type } 2 \text { diabetes mellitus }\end{array}$ \\
\hline 50 & $\mathrm{~K}-\operatorname{Glim}(2 \mathrm{mg})$ & Blue Cross Laboratories Ltd. & Tablet & $2 \mathrm{mg}$ & $\begin{array}{l}\text { lower the blood sugar levels } \\
\text { in type } 2 \text { diabetes mellitus }\end{array}$ \\
\hline 51 & Leride & Tablets (India) Limited & Tablet & $1 \mathrm{mg}$ & $\begin{array}{l}\text { lower the blood sugar levels } \\
\text { in type } 2 \text { diabetes mellitus }\end{array}$ \\
\hline 52 & Nabal & Win-Medicare Limited & Tablet & $2 m g$ & $\begin{array}{l}\text { lower the blood sugar levels } \\
\text { in type } 2 \text { diabetes mellitus }\end{array}$ \\
\hline 53 & Novaride $(4 \mathrm{mg})$ & Alembic Limited. & Tablet & $4 \mathrm{mg}$ & lower the blood sugar levels \\
\hline
\end{tabular}




\begin{tabular}{|l|l|l|l|l|l|}
\hline 54 & Zoryl & Intas Laboratories Pvt Ltd & Tablet & $1 \mathrm{mg}$ & $\begin{array}{l}\text { in type 2 diabetes mellitus } \\
\text { lower the blood sugar levels } \\
\text { in type 2 diabetes mellitus }\end{array}$ \\
\hline 55 & Zoryl (3 mg) & US Vitamins Limited & Tablet & $3 \mathrm{mg}$ & $\begin{array}{l}\text { lower the blood sugar levels } \\
\text { in type 2 diabetes mellitus }\end{array}$ \\
\hline 56 & Zoryl (4 mg) & B \& B (Micro Labs Ltd.) & Tablet & $4 \mathrm{mg}$ & $\begin{array}{l}\text { lower the blood sugar levels } \\
\text { in type 2 diabetes mellitus }\end{array}$ \\
\hline
\end{tabular}

\section{Conclusion:-}

The main purpose of writing this review was to collect all relevant data in an article about glimeperide. In this different types of formulation of glimepiride are made which is provided in summarized and concised way for a better knowledge and future formulated approach.

\section{Reference:-}

1. Shobha RG, Lohita M, Jaya PP, Madhavi R, Sunisitha B, Mounika D, Glimepiride: A Review of Analytical Methods, Asian J. Pharm. Ana. 2014; 4: 178-182.

2. Kishore K, Sudhakara RP, Srininvas RD, Maneshwar T, Kiran KV, Raju L, Preparation and characterization of oro dispersible tablets of glimepride- pvp k30 solid dispersion,Int.JBiol.Pharm.Res. 2013; 4: 547-555.

3. Saroj B, Mahesh KK, Ajay B, An overview on solid dispersion techniques implemented for dissolution enhancement of glimepiride,American J Pharmatech. Res, 2014; 4: 65-77.

4. Mayur DC, Raju OS, Laxmikant Z, Sasmita N, Sanjay BB, Solubility and dissolution enhancement of poorly water soluble glimepiride by using solid dispersion technique, Int. J Pharmacy Pharm.Sci, 2012; 4: 534-539.

5. Amidon GL, Lennernas H, Shah VP, Crison JR. A theoretical basis for a biopharmaceutic drug classification: the correlation of in vitrodrug product dissolution and in vivobioavailability, Pharm. Res. 1995; 12:413-420.

6. Nokhodchi A, Javadzadeh Y, Reza M, Barzegar JM, The effect of type and concentration of vehicles on the dissolution rates of a poorly water soluble drug (indomethacin) from liquisolid compacts. J Pharm.Sci. 2005; 8:18-25.

7. Wagh VT, Jagtap VA, Shaikh TJ, Nandedkar SY,Formulation and evaluation of glimepiride solid dispersion tablets for their solubility enhancement,J Advanced Scientific Res. 2012; 3:36-41.

8. Chawdhary KPR, Vijayasrinivas S., Indian Pharmacist, 2004; 2: 7-10.

9. Venkateswarlu G, Srinivasa RP, Nageswara RP, Ramakrishna G, Simultaneous determination of atorvastatin, metformin and glimepiride in human plasma by LCMS/ MS and its application to a human pharmacokinetic study,J Pharm. Sci. 2013;3: 9-19.

10. Tripathi KD, Essentials of medical pharmacology, $6^{\text {th }}$ Edition, 2008, Jaypeebrothers' medical publishers (P) limited, pp: 266-267.

11. Bhawandeep G, Tejvir K, Sandeep K, Gupta GD, Formulation and evaluation of glimepiride solid dispersion tablets, Asian J Pharmaceutics 2010;3:212-218.

12. Baliarsingh OP, Biswal S, Sahoo J, Murthy PN, Physicochemical properties of glimepiride in solid dispersions with polyethylene glycol 20000, Int. J Pharm. Sci. Nanotech. 2009; 2:537-543.

13. Venkatesh B, Indira S,Prathima S, Formulation and evaluation of glimepiride oral capsules, Int. J Pharm. Sci. Invention 2014; 3: 1-13.

14. Kiran T, Nalini S, Sistla R, Sadanandam M, Surface solid dispersion of glimepiride for enhancement of dissolution rate, Int. J PharmTech Res.2009;1822-831.

15. Neha P, Shyam SA, Formulation, development and evaluation of transdermal drug delivery system of Glimepiride, Int. J Pharmacy Pharm. Sci. Res. 2012; 2: 1-8.

16. Akash BP, Gondkari SB, Saudagari RB, Design and evaluation of mucoadhesivegel of glimepiride for nasal delivery, American J Pharmacy Health Res. 2013; 1: 67-77.

17. Tejakrishna M, Kishore VS, Rao KVSP,Sudheer B, Formulation and evaluation of mucoadhesivemicrobeads of glimepiride, Sch. Acad. J. Pharm. 2013; 2:199-208.

18. Mohd AH, Lokeswara VB,Narottam P, Formulation and evaluation of sustained release matrix tablets of glimepiride based on combination of hydrophilic and hydrophobic polymers,J Applied Pharm. Sci. 2012; 02: 101-107.

19. Harihar PM, DuraivelS, Effect of different binders and super disintegrants on formulation of glimepiride immediate release tablets by wet granulation method, Int. J Pharm. Clinical Res. 2012; 4: 44-47. 
20. Satheesh J, Laxman A, Ramesh NJ,Glimepiride fast disintegrating tablets: Formulation, evaluation and In vivodisintegration and dynamic studies, Int. J Pharm. Pharmaceutical Sci. 2016; 8: 271-278.

21. Sahu M, Formulation of dual component drug delivery of glimepiride and metformin hydrochloride for immediate and sustain release, Int. J Res. Ayurveda Pharm. 2010;1: 624-633.

22. Hyma.P et al,Formulation and characterization of novel self-microemulsifying drug delivery system ofglimepiride, The Experiment 2014; 24:1640-1648.

23. Subash CMP, Pandey VP, Formulation and evaluation of glimepiride loaded liposomes, Int. J Res. Pharm. Sci. 2015; 6: 333-338.

24. Samira K,Mohiuddin AB, Rana MS, Formulation and In vitro evaluation of glimepiride sustained release tablets: comparison with immediate release tablets, Bangladesh Pharm. Journal 2015; 18: 157-162.

25. Ethiraj T, Sujitha R, Ganesan V, Formulation and Invitroevaluationnanosuspensionof glimepiride,Int. J Pharm. 2013; 3: 875-882.

26. Ashwini V, Poojitha U, Surekha R, Geetha G, Srinath B, Formulation and evaluation of glimepiride fast dissolving tablet, Pharma Research Library 2016. 